\title{
Treasury Can Close a Potential Loophole in the Treatment of Deferred Foreign Income in the Tax Cuts and Jobs Act - Will It Act?
}

\section{Citation}

Stephen E. Shay, Treasury Can Close a Potential Loophole in the Treatment of Deferred Foreign Income in the Tax Cuts and Jobs Act - Will It Act? (Dec. 26, 2017).

\section{Permanent link}

http://nrs.harvard.edu/urn-3:HUL.InstRepos:34596007

\section{Terms of Use}

This article was downloaded from Harvard University's DASH repository, and is made available under the terms and conditions applicable to Other Posted Material, as set forth at http:// nrs.harvard.edu/urn-3:HUL.InstRepos:dash.current.terms-of-use\#LAA

\section{Share Your Story}

The Harvard community has made this article openly available.

Please share how this access benefits you. Submit a story.

\section{Accessibility}


December 26, 2017

Working Draft - Comments Welcome

Treasury Can Close a Potential Loophole in the Treatment of Deferred Foreign Income in the Tax Cuts and Jobs Act - Will It Act?

Stephen E. Shay*

\begin{abstract}
This paper points out a potential TJCA loophole allowing a reduction in aggregate foreign cash subject to the $15.5 \%$ rate unless Treasury takes steps to implement an anti-abuse rule. If Treasury does not act, aggressive taxpayers may be rewarded and cautious taxpayers may have incentives to make second-best uses of their offshore cash. This potential loophole can have material revenue consequences and is an example of the costs of rushed legislative consideration of tax legislation without adequate time to review and analyze bill text.
\end{abstract}

\footnotetext{
* Senior Lecturer on Law, Harvard Law School. This is a working draft. I thank Reuven Avi-Yonah, Patrick Driessen, Cliff Fleming and Susan Morse for comments on an earlier draft. The views expressed in this paper are my own and do not reflect those of any university or organization that I am affiliated with or of any client for which I render pro bono or consulting services. I disclose certain activities not connected with my position at Harvard Law School, one or more of which may relate to the subject matter of this paper, at https:/helios.law.harvard.edu/public/ConflictOfInterestReport.aspx?id=10794.
} 
Treasury Can Close a Potential Loophole in the Treatment of Deferred Foreign Income in the Tax Cuts and Jobs Act (TCJA) - Will It Act?

\author{
Stephen E. Shay
}

This note describes a potential cash repatriation loophole in the Tax Cuts and Jobs Act (“TCJA”) holiday rate taxation of deferred foreign income that could affect billions of dollars in revenue. The Treasury can readily foreclose the effect of cash repatriation to preserve this revenue through application of an anti-abuse rule. ${ }^{1}$ Will Treasury do so or will the new Administration decline to use congressionally sanctioned anti-abuse power and thereby extend the gift of the TCJA to corporations?

The TCJA would require inclusion in a U.S. multinational's income of deferred foreign income of its foreign subsidiaries. ${ }^{2}$ Deferred foreign income up to the aggregate foreign cash position is taxed at $15.5 \%$ and the excess is taxed at $8 \%$. The $7.5 \%$ rate difference $(15.5 \%-8 \%=7.5 \%)$ puts weight on the size of the aggregate foreign cash position.

Deferred foreign income is measured as the greater of the deferred foreign income amount at November 2, 2017 or at December 31, 2017. ${ }^{3}$ The measuring point for the aggregate foreign cash position, however, is different: it is the greater of (i) the average of the end of the two taxable years ending before November 2, 2017 (the November 2 measurement date), or (ii) the end of the last tax year beginning before January 1, 2018 (the second measurement date). ${ }^{4}$ An anti-abuse rule would allow but not require the IRS to disregard a transaction that has "a" principal purpose of reducing the aggregate foreign cash amount.

\title{
The Loophole Concern
}

The issue is whether a U.S. MNC can sidestep the "greater of" test by distributing cash before the second measurement date without running afoul of the anti-abuse rule. ${ }^{5}$ If so, it would be

\footnotetext{
${ }^{1}$ I applaud the Conference agreement's inclusion of authority at Section 965(o) to address loopholes identified in a paper I posted on SSRN in November regarding pre-2018 asset step-ups to avoid GILTI. See Stephen E. Shay, Tax Reform - Process Failures, Loopholes and Wealth Windfalls (November 21, 2017). Available at SSRN: https://ssrn.com/abstract=3076151. Such a regulation would have to be retroactive to be fully effective, which makes it more readily subject to challenge under Section 7805 if not filed within 18 months (the conference provision does not separately authorize retroactive issuance under Section 7805(b)(6) though one would think Section 7805(b)(3) provides adequate authority). Moreover, to be fully effective the regulation should recognize the gain recognition transaction but treat the income as not eligible for a reduced tax rate under 965.

${ }^{2}$ For ease of reading, I use the term "foreign subsidiary" instead of the statutory terms "deferred foreign income corporation" and "specified foreign corporation.” I use "deferred foreign income" to refer to accumulated post-1986 deferred foreign income.

${ }^{3}$ Note that this effective date approach will require the equivalent of an interim closing of the books on December 31 for every non-calendar year specified foreign corporation.

${ }^{4}$ In the case of a taxpayer with a June 30 fiscal year, such as Microsoft, or a September 30 fiscal year, such as Apple, the aggregate foreign cash provision could be affected by cash held on those dates in 2018 if it is higher than the November 2 measurement date amount. Many controlled foreign corporations with a U.S. calendar year parent November 30 taxable years, which is permitted under Section 898, so their second measurement date for the aggregate cash position would be November 30, 2018.

${ }^{5}$ Note also that a foreign subsidiary that has a non-calendar fiscal year will have a second measurement date after the effective date of the $100 \%$ dividends received deduction for foreign-source portions of dividends (which applies to distributions after December 31, 2017).
} 
possible for a U.S. MNC's foreign subsidiaries to distribute foreign cash assets before the second measurement date and thereby allow a larger amount of deferred foreign income to be eligible for the $8 \%$ rate instead of the $15.5 \%$ rate $^{6}$

The amount of the cash distribution for which this strategy could be effective would be the difference between the aggregate foreign cash position of the MNC's foreign subsidiaries determined for the November 2 measurement date (based on the cash position at the end of the foreign subsidiary's two years ending before November 2, 2017) and the projected foreign cash position as of the second measurement date (the end of the foreign subsidiary's last tax year beginning before January 1, 2018). This may not seem like much, but if effective the strategy could save Apple as much as $\$ 4$ billion (or more) in tax.

Using Apple as an example, the average of foreign cash Apple disclosed in its Form 10-K for its years ended on September 30, 2015 (\$216 billion) and September 30, 2016 (\$253 billion) was $\$ 234$ billion, which is its November 2 measurement date amount. Apple's foreign cash position at September 30, 2018 (which is the end of its last taxable year beginning before January 1, 2018) could be reasonably projected (based on its last several years) to be $\$ 36$ billion more than the $\$ 253$ billion in foreign cash it disclosed as of September 30, 2017, or $\$ 289$ billion. If Apple’s foreign subsidiaries have the same taxable year as Apple and distribute cash of \$55 billion ( $\$ 289$ billion - \$234 billion) before September 30, 2018 (the last taxable year beginning before 2018, Apple would potentially save $\$ 4.125$ billion in tax ( $\$ 55$ billion * 7.5\% = \$4.125 billion) assuming sufficient pre-December 31, 2017 deferred foreign income.

Under the statute's measurement dates for determining the aggregate foreign cash position, a U.S. MNC could cause a foreign subsidiary to distribute before its second measurement date, cash and net receivables so that its second measurement date cash position is no greater than the November 2 measurement date amount (the average at the prior 2 year ends). If the foreign subsidiary does make the distribution, the statute is clear (in 965(d)(3)) that, to the extent that the distribution is a dividend, the dividend does not reduce deferred foreign income for purposes of determining the Section 965 Subpart F inclusion - fine.

The question is whether a foreign subsidiary that has increased foreign cash over the November 2 measurement amount (which likely would include most U.S. MNCs with profitable foreign operations such as Apple and Microsoft) and that makes a cash distribution to the US parent before the second measurement date reduces the amount taxed at the $15.5 \%$ cash tax rate by the cash distributed (up to the point the aggregate foreign cash position does not exceed the November 2 measurement date amount). For purposes of this discussion, assume that the distribution is used by the U.S. parent for valid corporate purposes, such as to pay down debt, to pay a dividend to shareholders and or to buy-back shares.

Anti-abuse language (in new Section 965(c)(3)(F)) provides:

\footnotetext{
${ }^{6}$ For a fiscal year taxpayer, a distribution after December 31, 2017 that is not previously tax income under prior law Subpart $\mathrm{F}$ would be eligible for the $100 \%$ dividends received deduction (the GILTI minimum tax would not apply until the foreign subsidiary's first taxable year beginning after December 31, 2017).
} 
“(F) ANTI-ABUSE.- If the Secretary determines that a principal purpose of any transaction was to reduce the aggregate foreign cash position taken into account under this subsection, such transaction shall be disregarded for purposes of this subsection."

Even as changed in conference to "a" instead of "the" principal purpose, the anti-abuse provision may not address a cash distribution or other steps to effectively limit foreign cash to the November 2 measurement date amount.

\section{Unclear Legislative Intent}

The Joint Explanatory Statement of the Committee of Conference (the "Conference Report"), does not address directly how the anti-abuse provision in question should apply to a cash distribution that precedes the second measurement date. ${ }^{7}$ Is this authority only directed at reinvesting cash before the second measurement date in a non-cash asset (i.e., a transaction that seeks to alter the category of the item on the specified foreign corporation's balance sheet), as opposed to transactions that alter the balance sheet's assets and liabilities? Is a distribution of cash that reduces the balance sheet of the distributing company a "transaction" subject to scrutiny for this purpose?

When is "a" principal purpose of a cash dividend to reduce the aggregate foreign cash provision? Does it mean that any cash distribution after the November 2 measurement date that changes the aggregate foreign cash position of the specified foreign corporation before the second measurement date is subject to redetermination? Is it all facts and circumstances? Does the November 2 measuring date inoculate prescient cash distributions that were made prior to November 2 but after the most recent year ending before November 2? What if the dividend is paid by a fiscal year taxpayer after December 31, 2017? To the extent is it not treated as from earnings before January 1 , it would be eligible for the $100 \%$ dividends received deduction but the cash would nonetheless reduce the second measurement date aggregate foreign tax position. Which way does that cut in the principal purpose analysis?

\section{Uncertainty, De Facto Taxpayer Elections and Administrative Costs}

The anti-abuse rule does not apply automatically, but requires the Secretary's determination. While the anti-abuse rule could be applied by its terms to cash distributions, in the absence of authoritative guidance, there is enough fodder here for tax lawyers to argue that a taxpayer has a return position that a cash distribution for legitimate corporate purposes is not covered by the anti-abuse rule assuming the tax authority knows all of the facts (i.e., without regard to likelihood of review).

Absent clear guidance from the Treasury regarding the standard to be applied, an anti-abuse rule that awaits case-by-case determination invites a taxpayer to take a return position even if its auditors require that it be recorded as an increase in its uncertain tax position amount for

\footnotetext{
${ }^{7}$ The Conference Report does not make note of the fact that this anti-abuse authority was changed in the conference agreement from requiring that "the" principal purpose of a transaction be to reduce the aggregate foreign cash position in the House and Senate bills to requiring only that "a" principal purpose of a transaction be to reduce the aggregate foreign cash position.
} 
financial statement purposes. (There will be many uncertain tax positions and in large amounts after the TCJA.) Taxpayers will be aware that this current Administration's budget proposals would shrink IRS resources even as it supports enormously complicated legislation, which encourages incautious taxpayers in the absence of prompt guidance.

The amounts involved are material, even in the context of the TCJA's huge projected revenue loss. Normal considerations favoring a "level playing field" would argue strongly that it was not intended that the second measurement date be avoidable through self-help that in effect is more readily available to fiscal year taxpayers than calendar taxpayers. Moreover, it seems unlikely that this form of self-help was the assumption underlying the revenue estimate.

If the anti-abuse rule is intended to apply to cash distributions as it clearly can according to its terms, it is important to clarify that intent for taxpayers. The effects of this provision are frontend loaded and taxpayers will need to know for cash, tax and financial statement reporting reasons what the rules are.

\section{$\underline{\text { Possible Solutions }}$}

The most practical process alternative at this point is to rely on rapid administrative guidance. ${ }^{8}$ An approach that would be most consistent with giving content to the statute's "greater of" test would be for the Treasury to determine (i) that a distribution is a "transaction" for purposes of the anti-abuse rule, and (ii) that a cash distribution after November 2 has a principal purpose to reduce the aggregate foreign cash position except to the extent that the taxpayer can demonstrate that the cash distribution does not reduce the amount of deferred foreign income subject to a $15.5 \%$ tax rate. Alternatively, if cash distributions are intended to be allowed to maintain a November 2 measurement date amount of cash (and thereby reduce the amount subject to the $15.5 \%$ rate), it only is fair to say so in order to not disadvantage more cautious taxpayers who might otherwise have an incentive to "burn” cash in foreign operations.

Time is of the essence. If not addressed, this multi-billion dollar issue will be but one more example of the collateral damage of a process that did not allow sufficient review of actual statutory language to iron out its many policy and drafting anomalies.

\footnotetext{
${ }^{8}$ One approach to address this issue would be a joint letter by the Chairs (and Ranking Members) of the tax-writing committees. The complete exclusion by the majority of the minority from meaningful involvement in development of the legislation likely forecloses any realistic expectation of cooperation by the minority to fix a mess made by the majority. Another alternative would have been through a floor colloquy, but the accelerated passage of the bill precluded this alternative. I shared my concerns regarding this issue with majority and minority staffs, but it was too late for any action to be taken (had there been a desire to do so). I admit to some uncertainty about the status of a floor colloquy in final adoption of a bill passed unchanged by both houses, but it would have been better than no evidence of what was intended.
} 


\section{Appendix}

Section 965(c)(3):

(A) IN GENERAL.- The term 'aggregate foreign cash position' means, with respect to any United States shareholder, the greater of-

(i) the aggregate of such United States shareholder's pro rata share of the cash position of each specified foreign corporation of such United States shareholder determined as of the close of the last taxable year of such specified foreign corporation which begins before January 1, 2018, or

(ii) one half of the sum of-

(I) the aggregate described in clause (i) determined as of the close of the last taxable year of each such specified foreign corporation which ends before November 2, 2017, plus

(II) the aggregate described in clause (i) determined as of the close of the taxable year of each such specified foreign corporation which precedes the taxable year referred to in subclause (I).

(F) ANTI-ABUSE.- - If the Secretary determines that a principal purpose of any transaction was to reduce the aggregate foreign cash position taken into account under this subsection, such transaction shall be disregarded for purposes of this subsection. 